\title{
A CAUSALITY ANALYSIS ON FACTORS AFFECTING HOUSING PRICES: CASE OF TURKEY
}

\author{
DOI: 10.17261/Pressacademia.2021.1405 \\ JBEF- V.10-ISS.2-2021(2)-p.58-71
}

\section{Zeynep Colak}

Canakkale Onsekiz Mart Universty, Biga Faculty of Economics and Administrative Sciences, Department of Business, Canakkale, Turkey. zolak.84@gmail.com , ORCID: 0000-0003-0058-6809

\begin{tabular}{l} 
Date Received: March 29, $2020 \quad$ Date Accepted: June 12, 2021 \\
\hline To cite this document \\
Colak, Z., (2020). A causality on factors affecting housing prices: case of Turkey. Journal of Business, Economics and Finance (JBEF), 10(2),58-71. \\
Permanent link to this document: http://doi.org/10.17261/Pressacademia.2021.1405 \\
Copyright: Published by PressAcademia and limited licensed re-use rights only. \\
\hline
\end{tabular}

\begin{abstract}
Purpose- Crises can manifest themselves in many areas such as in political, social and economic areas, in the ordinary course of life. Especially in the practices related to the economic field, the crisis reaches a global scale and can affect many countries. Within the scope of the limitless dimensions of globalization, problems experienced in one country affect other countries as well. The aim of this study is to show the relationships between housing prices (Housing prices in Turkey after the 2008-2009 global financial crisis was subjected) and exchange rate, consumer price index (CPI), deposit interest rate, index of industrial production, employment.

Methodology- In this study, quantitative research method is used and the study has the feature of correlational research. The VAR model was used in the study and the stability of the data was tested with ADF (Augmented Dickey Fuller) and Phillips Perron (PP) unit root tests.

Findings- In the study, the long and short term relationships between housing price and the exchange rate, consumer price index, deposit interest rate, industrial production index and employment rate after the 2008-2009 global financial crisis impact for the period of 2010 January- 2019 December were examined with Johansen Cointegration and Granger Causality analyzes. The results show that there are long term relationships among the variables and there is a one-way short term relationship from deposit interest rate, USD / TL rate, industrial production index, CPI and employment to housing price index. According to the Johansen Cointegration test result, there is a long-term relationship between variables excluding CPI.

Conclusion- As a conclusion of the analyses, it is seen that macroeconomic variables have an effect on the increase of house prices in Turkey during the financial crisis and post-financial crisis period. Changes in house price and deposit interest rates, dollar/TL exchange rate, industrial production index, $\mathrm{CPI}$ and employment rates play a decisive role in the decrease or increase in house prices. This will have a major impact on the increase in housing demand and, as a result, the development of the construction sector. In this study, similar results were obtained from national and international studies.
\end{abstract}

Keywords: Housing prices, housing price index, Granger causality analysis, Johansen cointegration analysis. JEL Codes: G10, E44, C01.

\section{INTRODUCTION}

Crises can manifest themselves in many areas in the usual course of life. When it occurs within the political social economic field, it is in a position to affect more than one person. Especially in the applications of the economic field, the crisis reaches the quality of global dimensions and can affect many countries (Eryüzlü et al., 2020). Financial problems caused by mortgages in the last period of 2007 in the USA resulted in a global crisis in the last quarter of 2008 (Engin et al., 2016).

The positive situation of the houses, which are seen as both a necessity and an investment tool, with the price increase in the 2000 s, and the ability of banks to issue easy loans for the purchase of housing, have led people to buy houses. In particular, the rise of housing purchases for investment has caused house prices to rise. There has been a decrease in demand with the high level of house prices, and a systemic collapse with the failure to pay the loans on time (Dilber et al., 2016).

Within the scope of the limitlessness of the dimensions of the phenomenon of globalization, when the literature on the 2008 global financial crisis is examined with the effect of the problem in one country on other countries, the introduction of a network of chained relations formed by interrelated or triggering factors constitutes the framework of this study. The aim of this study on house prices in Turkey after the 2008-2009 global financial crisis; to show that the relations between the exchange rate, consumer 
price index (CPI), deposit interest rate, industrial production index and employment rate have an impact on house prices. The fact that there are studies covering these dimensions in the literature and that there has not been a study in which all of these dimensions are analyzed together reveals the scope and importance of the study. In the research part of the study, the fact that there was no data entry on housing prices between 2008 and 2010 covers the period between 2010 and 2019, and this is seen as a limitation of the work.

In the second part of the study, exchange rate, deposit interest rate, consumer price index (CPI), industrial production index and employment rates are evaluated as factors affecting house prices and their reflections in the literature are discussed. The third part is the research area and the house price indices realized in Turkey in 2010-2019; exchange rate, deposit interest rates, industrial production index, employment and CPI variables, which are thought to be related to house price indices, are examined. The fourth part, which is the last part of the study, includes analysis results and evaluations.

\section{FACTORS AFFECTING HOUSING PRICES}

\subsection{Effect of Exchange Rates}

In addition to affecting the domestic developments of a country, the exchange rate follows a different course due to the phenomenon developing in other countries. This is an important argument in terms of making sense of the extent of globalism. This instant reactionary mobility in the exchange rate also affects house prices. The instantaneous variability in house prices is closely related to which of the fluctuating exchange rates or fixed exchange rate applications are selected in the country's economic monetary policy (Badurlar, 2008).

In Zhu (2006), which investigated the housing financing structure in Indonesia, Singapore, Thailand and Korea, which adopted the fluctuating exchange rate practice in Asia, it concluded that exchange rates had a significant impact on house prices. In the study discussed by Eryüzlü and Ekici (2020), house prices are not an effective argument above the exchange rate in the short term; changes in the exchange rate have been identified as an important variable in the short term in determining house prices in Turkey. In their analysis Çetin and Doğaner (2017), reveal the relationship between the construction confidence index and house prices in Turkey. The fact that housing is a basic need constitutes the most important part of the spending items per household (Szeidl et al., 2004:105).

In their study in Dilber et al. (2016), they examined the factors in the house price index for Turkey. Accordingly, the most important share showing the decrease or increase in the house price index belongs to the exchange rate; other determinants of this situation are housing interest rates and inflation, respectively. In the period after the 2008 global financial crisis, it is possible to say that macroeconomic determinants have an impact on the increase or decrease in the house price index in Turkey. Instantaneous changes in interest rates, inflation and exchange rate remain decisive in the increase or decrease in house prices.

\subsection{Deposit Interest Rates}

Interest rates can be decisive on many assets as well as have an impact on housing prices. The increase or decrease in house prices affects investments made in the housing sector, borrowing of households or investment decisions and can also be determinant at the point of demand. The demand for housing includes economic activities in total (Zammit, 2010). In this context, the housing market; It can be the workplace of policymakers and researchers in determining growth, job creation and economic activities. The fact that the housing sector was seen as the cause of the 2008 global financial crisis suggests that more careful action should be made in investments in this area. The contribution of the housing sector to the economic field such as the creation of labor force in Turkey, the provision of contracting services abroad, its effectiveness in economic growth cannot be ignored. (Ayhan, 2018).

Short-term fluctuations in interest rates have significant effects on the housing sector and prices. This effect is capable of affecting all economic applications within the economic sphere. Short-term interest rates are associated with housing loans and house prices. The balance of payments in the maturity structure is also the decisive factor in housing loan prices. With monetary expansion and decreases in the price of housing loans, increases in mortgage demand are expected. This process increases the prices of houses with increased demand and the collateral value of housing loans, and increases the asset position and lending power of banks (Jorda et al., 2015: 37). Expansionary monetary policy practices reduce long- or short-term interest rates and reduce capital use costs. As a result, investments and total demand are increasing; otherwise, when the contractionary monetary policy is implemented, interest rates increase, while investments and total demand decrease (Canbay et al., 2020). Economic growth and increase in income affect the demand for housing loans and housing prices. Housing loan maturity structuring and interest rates in housing loans have an important effect on housing prices (Coşkun, 2016). 
Within the scope of monetary policies implemented by central banks, the number of studies aimed at analyzing the effects of change in interest rates on house prices and economic activities covers an important area in the literature. There are many studies in the literature that examine these effects with similar variables. These studies, which are generally carried out using VAR methodology, include lacoviello (2005), Goodhart and Hofmann (2008), Jarocinski and Smets (2008), Assenmacher-Wesche and Gerlach (2008), Carstensen, Hülsewig and Wollmershäuser (2009), Demary (2009), The studies of Milcheva and Sebastian (2016), Hofmann and Peersman (2017) are important in this context.

Canbay and Mercan (2020) in their work, shocks in interest rates, loan volume and growth have had a significant impact on house prices; it finds that house prices have no significant impact on growth, loan volume and interest rates. From here, it is more of a result for Turkey than a cause; in order for house prices to be a factor in economic growth, the need to maximize the functioning of financial markets arises. Halıcıoğlu (2007) stated that real income, urbanization and house prices rates are the determinants of housing demand; Üçal and Gökkent (2009) used consumer price index; Akkaş and Sayılgan (2015) on housing loan interest shocks; Coşkun and Ertuğrul (2016) determined that the housing rent index and the building cost index are the determinants of house prices.

\subsection{Consumer Price Index (CPI)}

The 2008 global financial crisis and global inflation brought about a re-discussion of the tie between inflation and real estate returns (Lee, 2013). The effects of inflation on housing prices and housing demand cause different opinions and many investigations. It has been analyzed that one of the factors in the increases in house prices is consumer prices as well as inflation accordingly (Poterba, 1992). The study by Andrews (2010) found that the fluctuation in inflation was a boost to house prices.

The impact of inflation on housing demand and house prices is shaping house prices. People who invest in housing attach importance to the protection of the market value of the housing and its capacity to increase its value. In this context, it can be said that there are many studies in the literature focusing on the ability of real estate prices to protect against inflation (Anari et al., 2002; Goetzmann et al., 2006; Zhou et al., 2010; Lee, 2013).

In the studies of Erol et al. (2008) and Ibrahim et al. (2009), it is emphasized that housing investments have the ability to protect against the risk of high inflation. In addition, Hossain et al. (2009), Kuang et al. (2015) the existence of a positive relation between inflation and house prices; Arestis et al. (2014) the existence of a negative relation between house prices and inflation; Christou et al. (2018) reveal the existence of a meaningful relationship between inflation and house prices. Korkmaz (2019) in the study of 26 regions of Turkey for the period 2010:01-2019-01 concluded that there is a relationship between house prices and inflation and that there are inflationary pressures on house prices, especially in some regions.

\subsection{Industrial Production Index}

Unpretermined changes in industrial production, money supply or interest rates and a certain delay determined by the speed of the spread can also affect house prices (Coşkun, 2016). Karadaş and Salihoğlu (2020) discussed the macroeconomic factors affecting housing prices in their study and showed that interest rates for housing loans, exchange rate and consumer price index affect negatively, while industrial production index affects positively house prices.

Islamoglu et al. (2019:97) revealed the relationship between the number of houses sold, the industrial production index and the construction costs index, population, building occupancy permit, consumer price index with the house price index for the period 2010:Q1- 2017:Q4 in Istanbul, Ankara and Izmir. The building occupancy permit was found to be statistically meaningless while negatively affecting house prices It has been found that the relationship between the house price index and other variables such as housing supply, industrial production index and construction cost variables is also statistically meaningless.

\subsection{Employment Rates}

Macroeconomic factors and the relationship between the house price index are an important research area especially for developing countries. Apergis et al. (2003) evaluated the house prices in Greece in their research in this direction. In their study, they stated that macroeconomic determinants such as employment, housing loan rates, inflation and money supply have a dynamic effect on house prices. According to the findings, it has been revealed that house prices respond to macroeconomic arguments.

Adams et al. (2010) discussed the relationships between house prices and employment rate, industrial production, real GDP and loan interest rates in their work based on 15 OECD countries. They showed that the macroeconomic variables included in the study positively affected house prices. 
Lebe et al. (2014) examined the determinants of housing demand by classifying them as short and long term and found that the factors that positively affected housing demand were per capita income and industrialization; they have determined that it negatively affects the agricultural employment rate and interest rates

\section{Methods}

\subsection{Research Pattern}

In this study, the relationships between housing prices that are shaped after the 2008-2009 global financial crisis impact and the factors (Exchange rate, deposit interest rate, consumer price index (CPI), employment and industrial production index) that might have an effect on housing prices were examined. In determining the time interval; 2010 January was selected as the beginning date because of its' being after 2008-2009 global financial crisis. 2019 December was selected as the end time because of its' being the last date before Covid-19 pandemic that affected not only housing sector but also almost all sectors in the world. This study in which quantitative research method is used has the feature of correlational research. Correlational research studies are conducted to reveal relationships between two or more variables and provide clues about cause-effect relationship (Büyüköztürk et al., 2018).

\subsection{Data set}

In the research, housing prices that occurred in the period of 2010-2019 and the variables of exchange rate, consumer price index (CPI), deposit interest rate, employment and industrial production index which are likely to affect housing prices were used.

$$
\begin{aligned}
\Delta l n_{-} h p i t=\beta 0+ & \beta 1 \Delta l n_{-} d i r t+\beta 2 \Delta l n_{-} \text {exct }+\beta 3 \Delta l n_{-} i n d p r d c t+\beta 4 \Delta \Delta l n_{-} c p i \\
& +\beta 5 \Delta l n_{-} e m p l y t
\end{aligned}
$$

In the equations the meanings of abbreviations are as follows;

"hpi" for the housing prices;

"exc" for \$ / TL exchange rates;

"dir" for interest rates on deposits;

"indprdc" for industrial production indexes;

"emply" for employment rates;

"cpi" for consumer price indexes in Turkey.

" $\Delta$ " statement indicates that first order difference is applied to the relevant variable;

$" \Delta \Delta$ " statement indicates that second difference is applied to the relevant variable;

The expression "In" indicates that a logarithmic transformation is applied to the relevant variable.

All of the data in the study were taken from the official website of the Central Bank of Turkey. Descriptive statistics for the variables in the study are as in Table 1.

Table 1: Descriptive Statistics of the Variables in the Study

\begin{tabular}{lllll}
\hline Variable & Minimum & Maximum & Mean & $\begin{array}{l}\text { Standard } \\
\text { Deviation }\end{array}$ \\
\hline hpi & 45,36 & 118,76 & 77,07 & 23,49 \\
\hline dir & 5,95 & 24,11 & 10,84 & 4,09 \\
\hline exc & 1,42 & 6,37 & 2,89 & 1,39 \\
\hline indprdc & 56,84 & 129,99 & 95,95 & 16,78 \\
\hline cpi & 174,07 & 440,50 & 267,45 & 74,78 \\
\hline emplyt & 39,20 & 48,35 & 44,99 & 2,10 \\
\hline
\end{tabular}

When the data in Table 1 is analyzed, for the period January 2010 - December 2019;

The mean of the housing price index is 77.07 ; the minimum value is 45.36 (January 2010) and the maximum value is 118.76 (December 2019); the mean of the deposit interest rate is 24.11; the minimum value is 5.95\% (May 2013) and the maximum value is $24.11 \%$ (October 2018); the mean for USD / TL exchange rate is 2.89; the minimum value is 1.42 (October 2010) and its maximum value is 6.37 (September 2018); the mean of the industrial production index is 95.95; Its minimum value is 56.84 (January 2010 ) and its maximum value is 129.99 (December 2017); the mean of the consumer price index (CPI) is 267.45; its minimum value is 174,07 (January 2010) and its maximum value is 440,50 (December 2017); the mean for the employment rate is $44.99 \%$; it is seen that the minimum value is $39.20 \%$ (January 2010 ) and the maximum value is $48.35 \%$ (June 2018 ). 
The figures of the related variables used in the study are presented below, respectively.

Figure 1: House Price Indexes for January 2010-December 2019

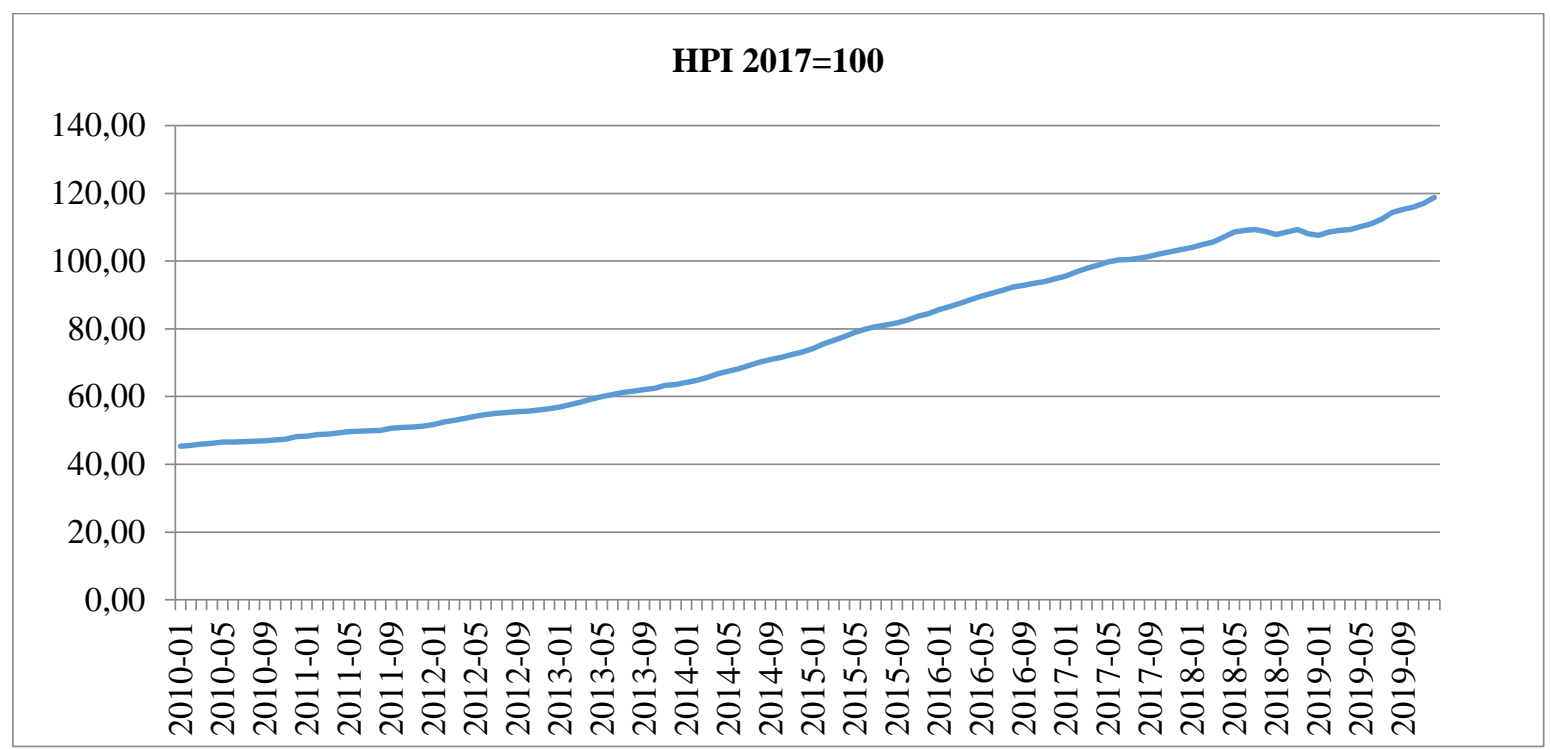

The figure of the housing price index for the period January 2010-December 2019 is as in Figure 1. It is seen that the housing price index has a steady increasing trend in general, except for the horizontal course between 2018 June-2019 April.

\section{Figure 2: Deposit Interest Rate for January 2010-December 2019}

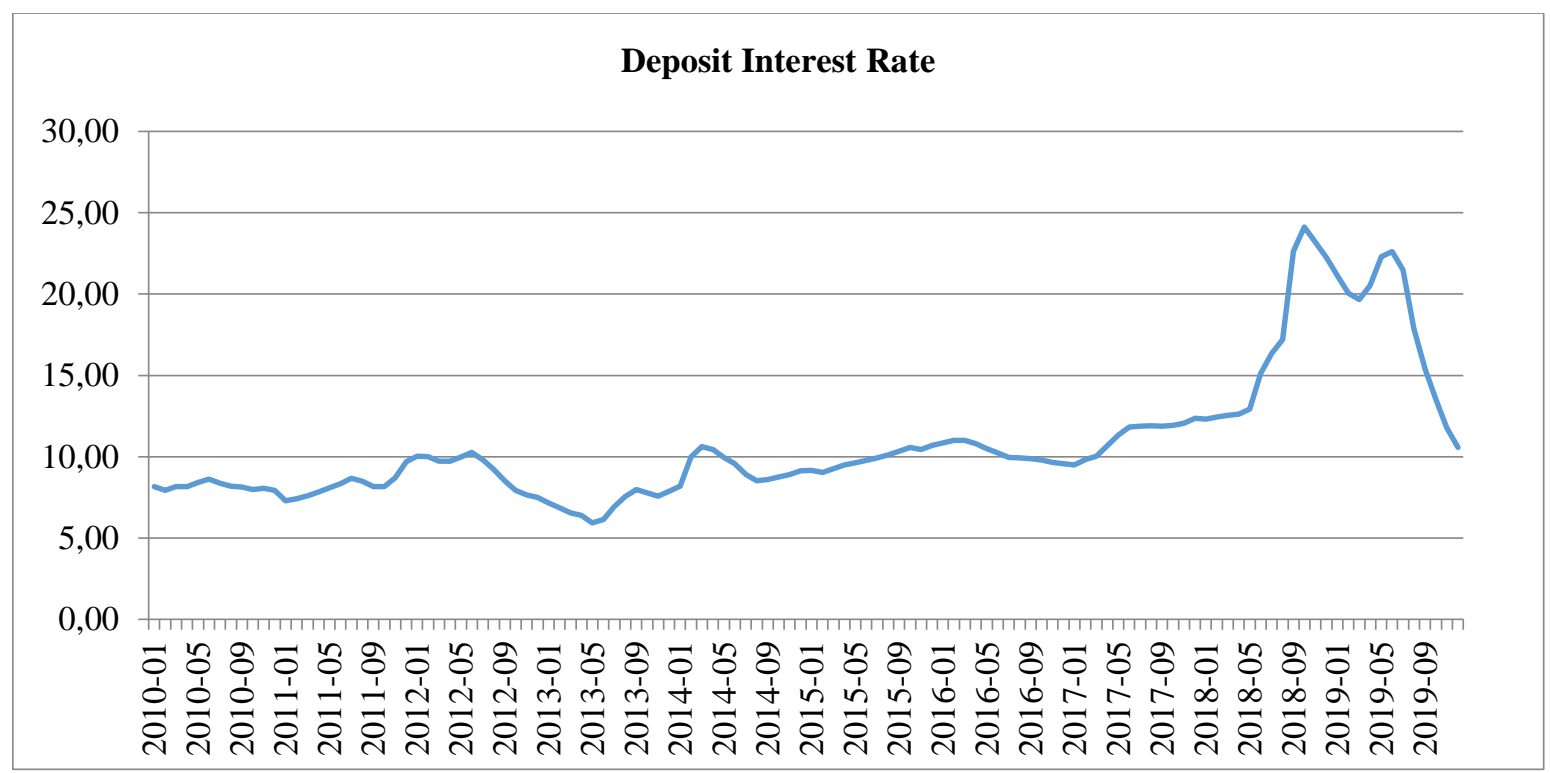

The figure of the deposit interest rate for the period January-2019 December 2010 is as in Figure 2. It is observed that the deposit interest rate, which fluctuates between January 2010 and January 2017, follows a generally horizontal course and has a slight increasing trend between January 2017 and May 2018. But from May 2018 until October 2018 it rises very sharply and after that period it has a sharp decline trend except for the rising period between March 2019 and June 2019. 
Figure 3: USD / TL Exchange Rate for January 2010 - December 2019

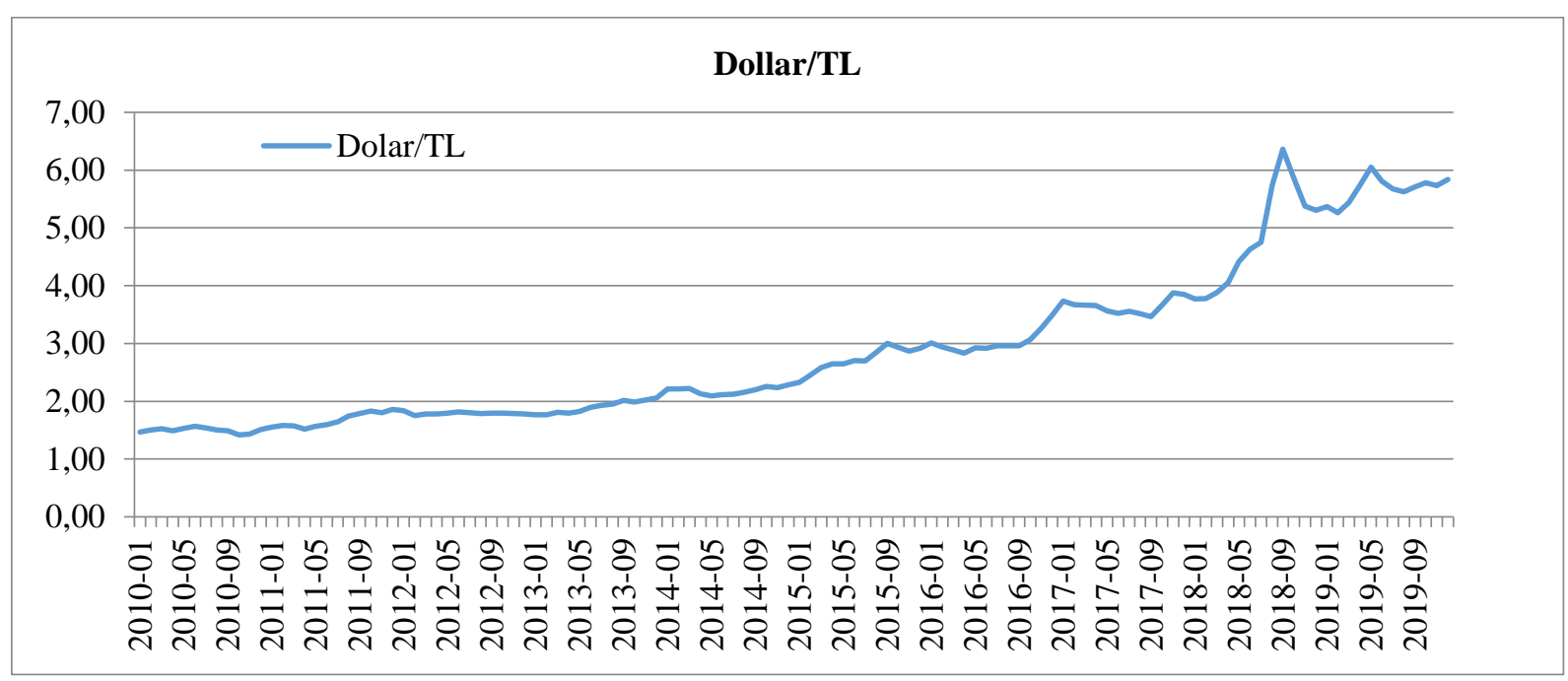

The figure of the USD / TL exchange rate for the period January-2019 December is as in Figure 3. It is observed that the USD / TL exchange rate, which generally has a slight upward trend between January 2010 and July 2014, shows a more linear upward trend in the 2014 July - 2017 October period. It is seen that the dollar / TL exchange rate, which rises very sharply between October 2017 and September 2018, follows a fluctuating course since September 2018.

Figure 4: The Industrial Production Index for January 2010-December 2019

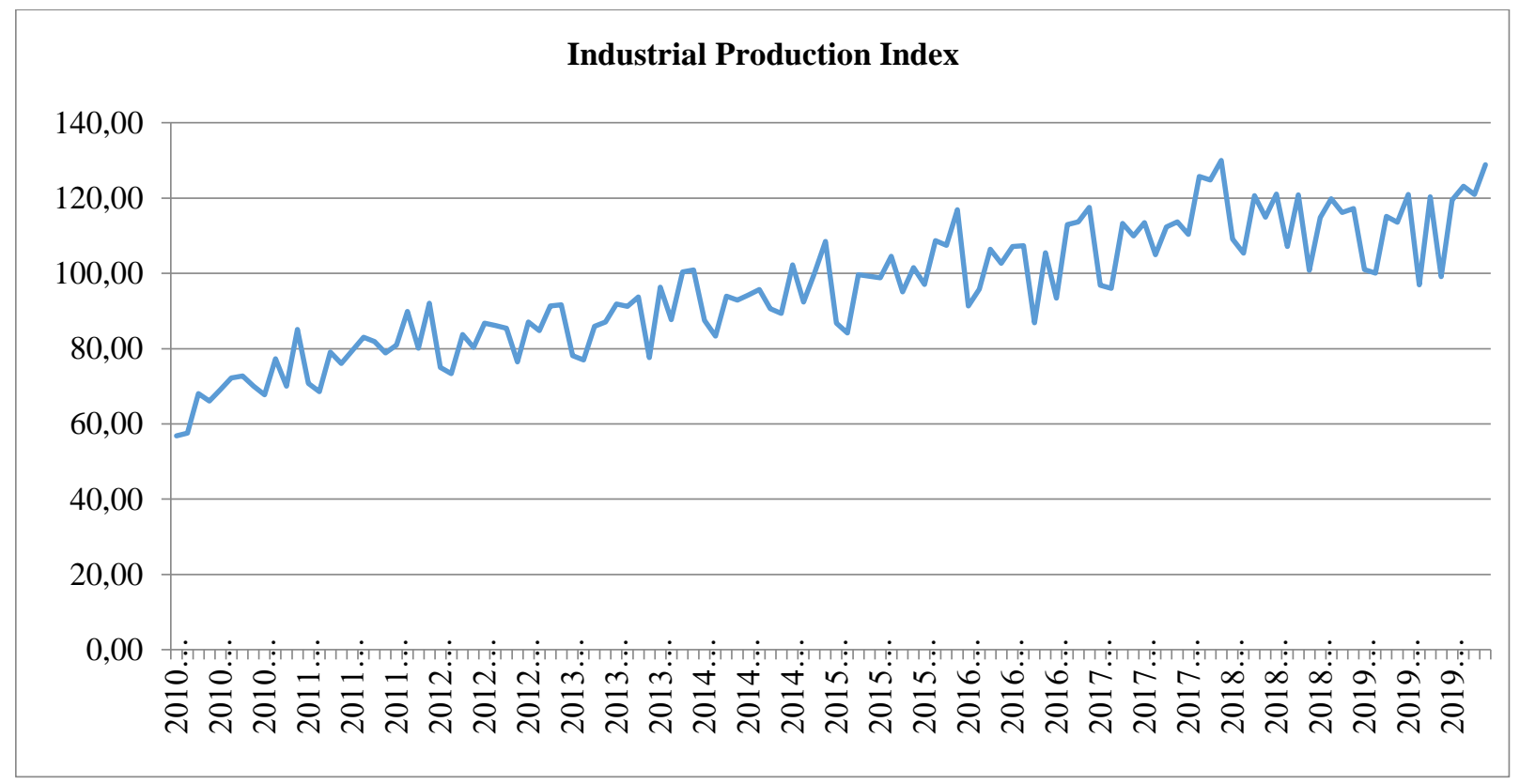

The figure of the industrial production index for the period of January 2010-December 2019 is as in Figure 4. It is seen that the industrial production index has a fluctuating and slightly rising trend in general for the whole period. 
Figure 5: The Consumer Price Index (CPI) for the 2010 January-2019 December Period

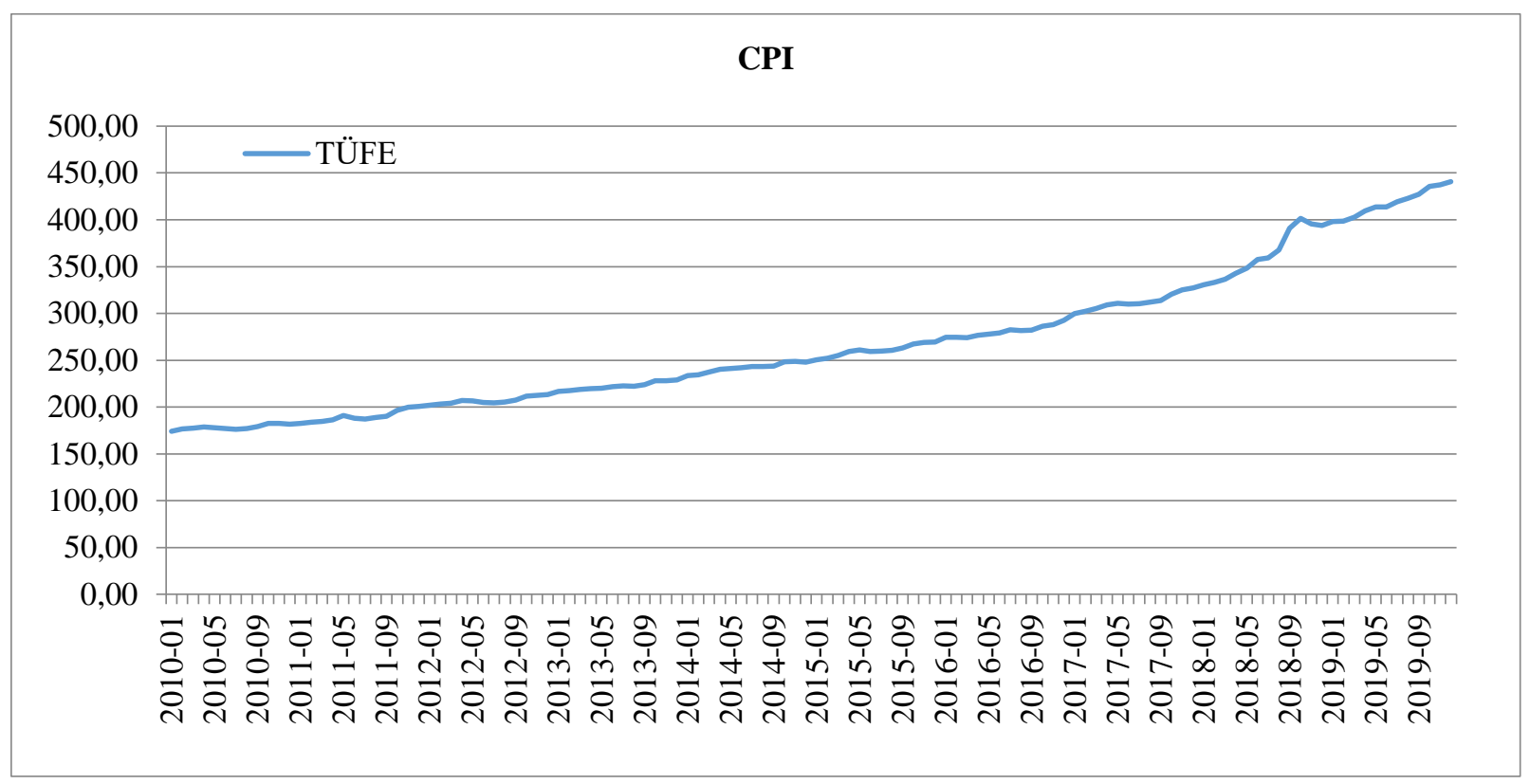

The figure of the consumer price index for the period January 2010-December 2019 is as in Figure 5. It is seen that it is in a stable, moderate upward trend in general between January 2010 and December 2019.

Figure 6: Employment Rate for January 2010-December 2019

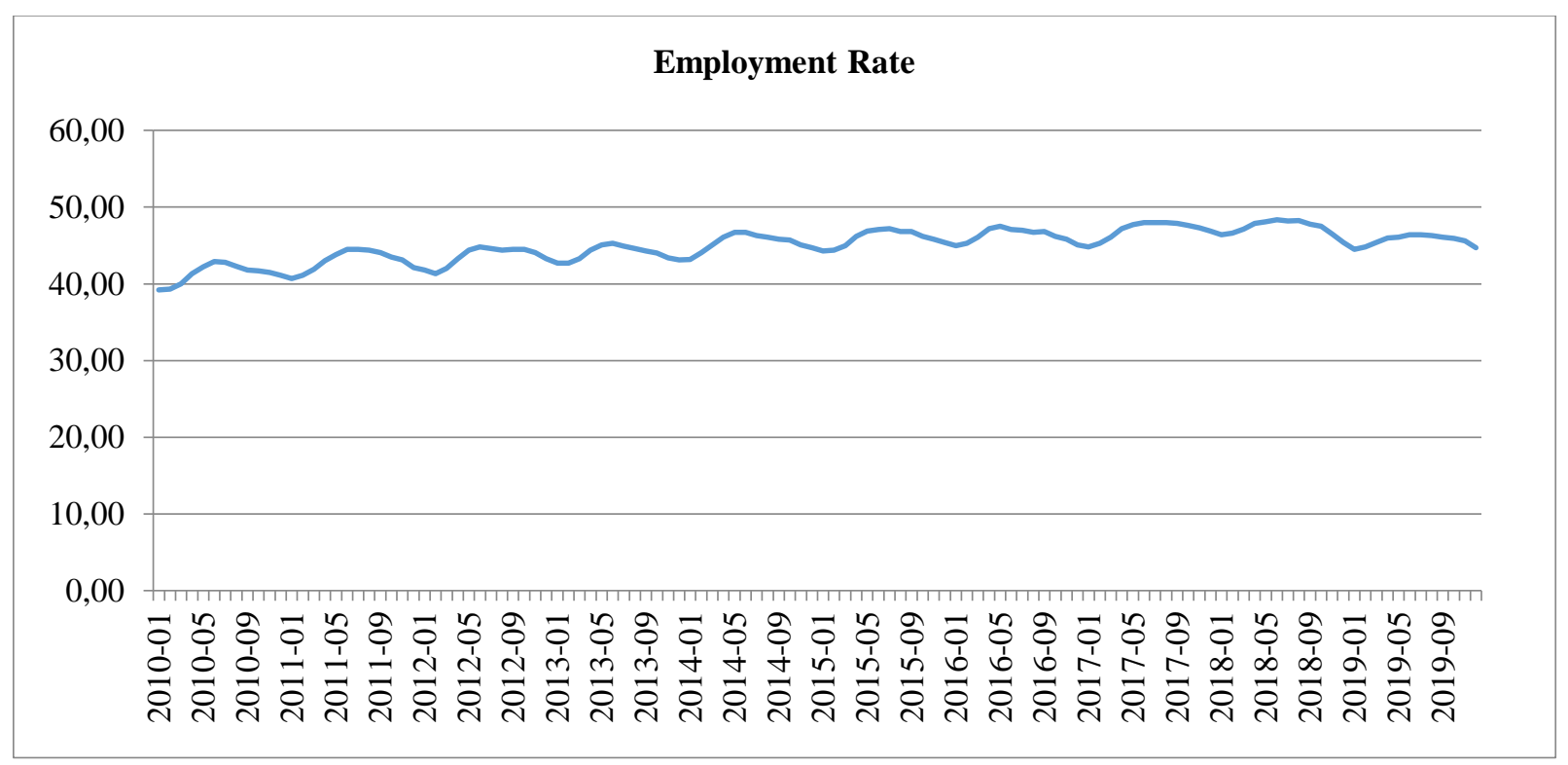

Figure of the employment rate for the period January 2010-December 2019 is as in Figure 6 . It is observed that the employment rates follow a fluctuating course between January 2010 and December 2019, and generally has a slightly rising trend. In addition, the rate thatgenerally increases in the first 6 months and decrease in the last 6 months shows that the employment rate has a seasonality. 


\section{ANALYSIS}

For the reliability of the VAR model results, first, stationarity of the data was tested (Güriş et al., 2017). The stationarity of the data was tested with ADF (Augmented Dickey Fuller) and Phillips Perron (PP) tests.

Table 2: Results of Unit Root Tests

\begin{tabular}{lllll}
$\begin{array}{l}\text { Related } \\
\text { Variable }\end{array}$ & ADF & PP & Test Stat. & $\begin{array}{l}\text { Probability } \\
\text { Value }(\mathbf{p})\end{array}$ \\
\cline { 2 - 5 } & Test Stat. & $\begin{array}{l}\text { Probability } \\
\text { Value }(\mathbf{p})\end{array}$ & -18.34560 & 0.000 \\
\hline$\Delta \ln$ hpi & -7.232547 & 0.000 & -24.46354 & 0.000 \\
\hline$\Delta \ln$ _dir & -5.183385 & 0.000 & -7.236796 & 0.000 \\
\hline$\Delta \ln$ exc & -7.346835 & 0.000 & -8.968543 & 0.000 \\
\hline$\Delta \ln$ indprdc & -7.309320 & 0.003 & -13.19883 & 0.000 \\
\hline$\Delta$ In_cpi & -6.152753 & 0.000 & &
\end{tabular}

The ADF and PP unit root test results of the variables used in the study are shown in Table 2. Accordingly, when logarithm and first degree difference processes are applied to housing price index, deposit interest rate, exchange rate, industrial production index and employment rate they get stationary. For the CPI data, after logarithm and second degree processes, it gets stationary $(p<0.05)$ (Güriş, 2017). After data's stationarity checks, the appropriate lag length for the VAR model was calculated.

Table 3: Appropriate Lag Length Calculation

\begin{tabular}{lllllll}
\hline $\begin{array}{l}\text { Delay } \\
\text { Length }\end{array}$ & LogL & LR & FPE & AIC & SC & HQ \\
\hline $\mathbf{0}$ & 1439.762 & NA & $3.27 \mathrm{e}-20$ & -27.84004 & -27.68656 & -27.77787 \\
\hline $\mathbf{1}$ & 1586.277 & 273.1160 & $3.83 \mathrm{e}-21$ & -29.98596 & $-28.91161^{*}$ & -29.55081 \\
\hline $\mathbf{2}$ & 1667.956 & 142.7405 & $1.59 \mathrm{e}-21$ & -30.87294 & -28.87771 & -30.06480 \\
\hline $\mathbf{3}$ & 1729.042 & 99.63415 & $9.93 \mathrm{e}-22$ & -31.36003 & -28.44393 & -30.17891 \\
\hline $\mathbf{4}$ & 1778.611 & 75.07567 & $7.89 \mathrm{e}-22$ & -31.62351 & -27.78653 & -30.06940 \\
\hline $\mathbf{6}$ & 1816.228 & 52.59081 & $8.09 \mathrm{e}-22$ & -31.65491 & -26.89705 & -29.72781 \\
\hline $\mathbf{7}$ & 1870.559 & 69.62798 & $6.17 \mathrm{e}-22$ & -32.01085 & -26.33212 & -29.71077 \\
\hline $\mathbf{8}$ & 1916.404 & 53.41227 & $5.77 \mathrm{e}-22$ & -32.20203 & -25.60241 & -29.52896 \\
\hline $\mathbf{9}$ & 1966.934 & 52.98214 & $5.19 \mathrm{e}-22$ & -32.48415 & -24.96366 & -29.43809 \\
\hline $\mathbf{1 0}$ & 2030.124 & 58.89578 & $3.89 \mathrm{e}-22$ & -33.01211 & -24.57075 & -29.59307 \\
\hline $\mathbf{1 1}$ & 2103.574 & 59.90066 & $2.60 \mathrm{e}-22$ & -33.73929 & -24.37705 & -29.94726 \\
\hline $\mathbf{1 2}$ & 2142.185 & 26.99079 & $3.85 \mathrm{e}-22$ & -33.79001 & -23.50689 & -29.62499 \\
\hline $\mathbf{1 3}$ & 2195.020 & 30.77733 & $5.07 \mathrm{e}-22$ & -34.11689 & -22.91290 & -29.57889 \\
\hline $\mathbf{1 4}$ & 2270.428 & 35.14165 & $5.47 \mathrm{e}-22$ & -34.88210 & -22.75723 & -29.97111 \\
\hline $\mathbf{1 5}$ & 2400.903 & 45.60289 & $2.96 \mathrm{e}-22$ & -36.71656 & -23.67081 & -31.43259 \\
\hline
\end{tabular}

As can be seen in Table 3, the most suitable lag length is calculated as "15". The error term for the specified lag length should provide some assumptions. The assumption of no autocorrelation was tested with the LM autocorrelation test.

Table 4: Results for LM Test

\begin{tabular}{lllllll}
\hline Delay Lenght & LRE Stat. & sd & Probability (p) & $\begin{array}{l}\text { Rao } \\
\text { F-Stat. }\end{array}$ & sd & Probability (p) \\
\hline $\mathbf{1}$ & 61.83610 & 36 & 0.0047 & 2.372003 & $(36,7.2)$ & 0.1146 \\
\hline $\mathbf{2}$ & 91.12061 & 36 & 0.0000 & 8.443617 & $(36,7.2)$ & 0.0031 \\
\hline $\mathbf{3}$ & 66.08320 & 36 & 0.0016 & 2.866232 & $(36,7.2)$ & 0.0721 \\
\hline $\mathbf{4}$ & 45.02390 & 36 & 0.1439 & 1.082883 & $(36,7.2)$ & 0.4984 \\
\hline
\end{tabular}




\begin{tabular}{lllllll}
\hline $\mathbf{6}$ & 68.74562 & 36 & 0.0008 & 3.223417 & $(36,7.2)$ & 0.0532 \\
\hline $\mathbf{7}$ & 70.83510 & 36 & 0.0005 & 3.532657 & $(36,7.2)$ & 0.0416 \\
\hline $\mathbf{8}$ & 56.99330 & 36 & 0.0144 & 1.904942 & $(36,7.2)$ & 0.1870 \\
\hline $\mathbf{9}$ & 46.48247 & 36 & 0.1133 & 1.162662 & $(36,7.2)$ & 0.4515 \\
\hline $\mathbf{1 0}$ & 55.84974 & 36 & 0.0185 & 1.807661 & $(36,7.2)$ & 0.2085 \\
\hline $\mathbf{1 1}$ & 47.42148 & 36 & 0.0964 & 1.216632 & $(36,7.2)$ & 0.4223 \\
\hline $\mathbf{1 3}$ & 41.01012 & 36 & 0.2601 & 0.886662 & $(36,7.2)$ & 0.6321 \\
\hline $\mathbf{1 4}$ & 57.40372 & 36 & 0.0132 & 1.940994 & $(36,7.2)$ & 0.1797 \\
\hline $\mathbf{1 5}$ & 52.58483 & 36 & 0.0366 & 1.553976 & $(36,7.2)$ & 0.2799 \\
\hline
\end{tabular}

The LM test results are listed in Table 4. As seen in Table 4, the fifteenth-order LM probability value of the VAR (15) model is greater than 0.05 according to both LRE statistics $(p=0.69)$ and Rao statistics $(p=0.9021)$ showing that there is no autocorrelation problem (Güriş, 2017). Whether there is a heteroskedasticity problem in the created VAR model was checked with White test.

Table 5: Results for White Test

\begin{tabular}{|c|c|c|c|c|c|}
\hline Chi-square Stat. & df & Probability (p) & & & \\
\hline 1237.272 & 1260 & 0.6708 & & & \\
\hline \multicolumn{6}{|c|}{ Separate Components } \\
\hline Dependent & $\mathbf{R}^{2}$ & $F(60,52)$ & Probability (p) & $\begin{array}{l}\text { Chi-square Stat. } \\
(60)\end{array}$ & Probability (p) \\
\hline res1*res1 & 0.639788 & 1.539321 & 0.0568 & 72.29600 & 0.1327 \\
\hline res2*res2 & 0.583136 & 1.212349 & 0.2398 & 65.89438 & 0.2803 \\
\hline res3*res3 & 0.545131 & 1.038646 & 0.4465 & 61.59985 & 0.4186 \\
\hline res4*res4 & 0.532395 & 0.986751 & 0.5223 & 60.16068 & 0.4699 \\
\hline res5*res5 & 0.638286 & 1.529336 & 0.0596 & 72.12636 & 0.1357 \\
\hline res6*res6 & 0.555178 & 1.081680 & 0.3878 & 62.73516 & 0.3795 \\
\hline res $2 *$ res 1 & 0.549371 & 1.056572 & 0.4216 & 62.07896 & 0.4019 \\
\hline res3*res1 & 0.574790 & 1.171542 & 0.2808 & 64.95127 & 0.3083 \\
\hline res3*res2 & 0.583751 & 1.215420 & 0.2369 & 65.96386 & 0.2783 \\
\hline res4*res1 & 0.522645 & 0.948894 & 0.5798 & 59.05891 & 0.5101 \\
\hline res4*res2 & 0.455256 & 0.724295 & 0.8863 & 51.44393 & 0.7764 \\
\hline res4*res3 & 0.529741 & 0.976288 & 0.5381 & 59.86071 & 0.4808 \\
\hline res5*res1 & 0.406732 & 0.594168 & 0.9739 & 45.96068 & 0.9092 \\
\hline res5*res2 & 0.540517 & 1.019511 & 0.4739 & 61.07842 & 0.4370 \\
\hline res5*res3 & 0.559517 & 1.100872 & 0.3631 & 63.22546 & 0.3632 \\
\hline res5*res4 & 0.540464 & 1.019292 & 0.4743 & 61.07239 & 0.4372 \\
\hline res6*res1 & 0.512899 & 0.912569 & 0.6356 & 57.95764 & 0.5507 \\
\hline
\end{tabular}




\begin{tabular}{llllll} 
res6*res2 & 0.557534 & 1.092052 & 0.3743 & 63.00132 & 0.3706 \\
\hline res6*res3 & 0.480089 & 0.800287 & 0.7983 & 54.25011 & 0.6848 \\
\hline res6*res4 & 0.532206 & 0.986000 & 0.5234 & 60.13925 & 0.4707 \\
\hline res6*res5 & 0.519030 & 0.935248 & 0.6008 & 58.65040 & 0.5252
\end{tabular}

Table 5 contains the results of the White test. As a result of the White test, it is seen that the integrated test probability value and the seperate components probability values are greater than 0.05 . This shows that the error terms have constant variance, in other words, there is no heteroskedasticity problem (Güriş, 2017).

Whether / not the VAR model fulfills stability assumption is tested by examining the places of the inverse roots of the AR Characteristic polynomial in the unit circle.

\section{Figure 7: Stability Graph of Created VAR Model}

\section{Inverse Roots of AR Characteristic Polynomial}

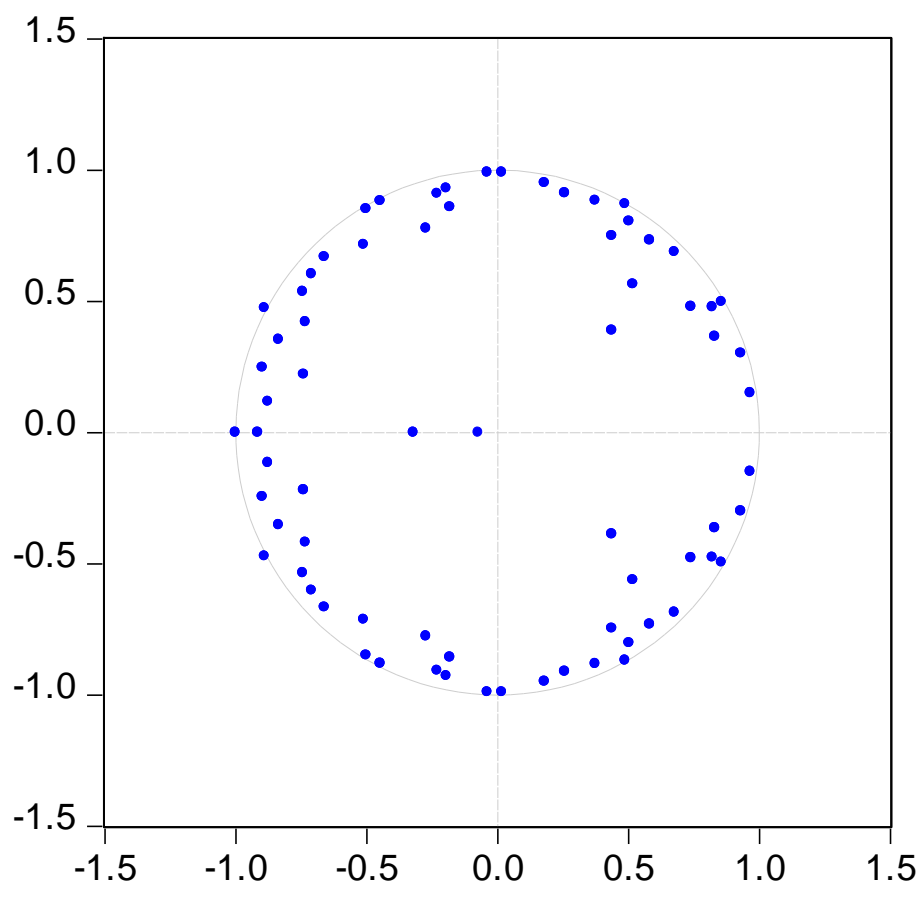

As can be seen in Figure 7, the inverse roots of the AR characteristic polynomial are located within the unit circle boundaries showing that the model does not pose any problem in terms of stability (Özgen \& Güloğlu, 2004).

Johansen cointegration test was applied to determine long term relationships after the assumptions check. Consumer price index wasn't included in the cointegration test because of its being stationary at the second level. The results are in Table 6. 
Table 6: Results for Johansen Cointegration Test

\begin{tabular}{|c|c|c|c|c|c|c|}
\hline HO & Trace Stat. & $\begin{array}{l}0.05 \text { Critical } \\
\text { Value }\end{array}$ & p & $\begin{array}{l}\text { Max-Eigen } \\
\text { Stat. }\end{array}$ & $\begin{array}{l}0.05 \text { Critical } \\
\text { Value }\end{array}$ & p \\
\hline No cointegration $(r=0)$ & 334.8253 & 76.97277 & 0.0001 & 149.2862 & 34.80587 & 0.0000 \\
\hline At most $1 .(r \leq 1)$ & 185.5391 & 54.07904 & 0.0000 & 70.67980 & 28.58808 & 0.0000 \\
\hline At most $2(r \leq 2)$ & 114.8593 & 35.19275 & 0.0000 & 58.09442 & 22.29962 & 0.0000 \\
\hline At most $3(r \leq 3)$ & 56.76484 & 20.26184 & 0.0000 & 37.10350 & 15.89210 & 0.0000 \\
\hline
\end{tabular}

Both trace and max-eigen statistics show that cointegration exists among the variables, in other words there are long term relationships among the related variables $(p<0.05)$. Finally, Granger causality test was performed to see the short term relationships among the variables. The results are in Appendix 1.

When "Housing price index" is determined as the dependent variable, it is seen that the deposit interest rate, the USD / TL exchange rate, the industrial production index, the CPI and the employment rate are the reasons for the "Housing price index" $(p<0.05)$.

In the equations in which the independent variable is determined as the "Housing price index", it is seen that the probability values of the "Housing price index" are greater than 0.05 ( $p>0.05)$. In other words, the housing pricing index is not a cause of the deposit interest rate, the USD / TL exchange rate, the industrial production index, the CPI and the employment rate.

\section{CONCLUSION}

In determining housing prices in Turkey, the housing price index and deposit interest rates, the Dollar / TL rate, industrial production index, CPI and employment rates are important variables. When the factors in determining house prices for Turkey are examined, while the most important share of the house price index showing the decrease or increase belongs to the exchange rate, the other determinants of this situation are housing interest rates and inflation, respectively. It is possible to say that macroeconomic determinants have an impact on the increase or decrease in the house price index in Turkey during the 2008 global financial crisis and after this period. Interest rates, inflation and instantaneous changes in the exchange rate remain decisive in increasing or decreasing house prices.

In the study, the long and short term relationships between housing price and the exchange rate, consumer price index, deposit interest rate, industrial production index and employment rate after the 2008-2009 global financial crisis impact for the period period of 2010 January - 2019 December were examined with Johansen Cointegration and Granger Causality analyzes. The results show that there are long term relations among the variables and there is a one-way short term relationship from deposit interest rate, USD / TL rate, industrial production index, CPI and employment to housing price index. According to the Johansen Cointegration test result, there is a long-term relation between variables excluding CPI.

In Apergis et al. (2003) study, the dynamic effects of macroeconomic variables such as inflation, employment loan rates and CPI on new house prices in Greece were analyzed. According to the results obtained, housing prices respond to all macroeconomic variables considered. The study also confirms the positive demand-side effect of the CPI on house prices. As a result of the study conducted by Lotz et al. (2013) for South Africa, it has been observed that there is a cointegration relation between house prices and the CPI in the long term. The results of these studies are similar to our findings. The results of the industrial production index variable, Valadez (2010), Kepili et al. (2011), Zandi et al. (2015) 's results. In this study, similar results were obtained from national and international studies.

As a result of the analyses, it is seen that macroeconomic variables have an effect on the increase of house prices in Turkey during the financial crisis and post-financial crisis period. Changes in house price and deposit interest rates, dollar/TL exchange rate, industrial production index, $\mathrm{CPI}$ and employment rates play a determining role in the decrease or increase in house prices. This will have a major impact on the increase in housing demand and, as a result, the development of the construction sector. With the measures to be taken by the government, there will be an increase in housing demand and therefore in house prices. Among these measures, in order to increase the housing investment demand, there are practices such as increasing the housing loan 
volume by decreasing the housing loan interest rates and extending the maturities, providing tax advantages and keeping the inflation at a certain level.

The study was limited to the case of Turkey which means that the findings may not be generalizable to other countries. Therefore, the study needs to be repeated in different countries to compare the findings.

\section{REFERENCES}

Adams, Z.ü \& Füss, R. (2010). Macroeconomic determinants of international housing markets. Journal of Housing Economics, 19 (1), 38-50.

Akkaş, M. E., \& Sayılgan, G. (2015). Konut fiyatları ve konut kredisi faizi: Toda-Yamamoto nedensellik testi. Journal of Economics, Finance \& Accounting, 2 (4), 572-583.

Anari, A., \& Kolari, J. (2002). House prices and inflation. Real Estate Economics, 30 (1), 67-84.

Andrews, D. (2010). Real house prices in oecd countries: the role of demand shocks and structural and policy factors. OECD Economics Department Working Paper, No: 831.

Apergis, N., \& Rezitis A. (2003), "Housing prices and macroeconomic factors in Greece: prospects within the EMU. Applied Economics Letters, 10, 799-804.

Arestis, P., \& Gonzalez, A.R. (2014). Bank credit and the housing market in OECD countries. Journal of Post Keynesian Economics, 36 (3), $467-490$.

Assenmacher-Wesche, \& K. Gerlach, S. (2008). Monetary policy, asset prices and macroeconomic conditions: a panel-var study. National Bank of Belgium Working Paper Research, 149, 1-37.

Ayhan, F. (2018). İnşaat sektörünün Türkiye ekonomisine etkilerine ilişkin bir analiz. (Ed. Ayhan O., M.R. İnce, S. Demir), Dünden Bugüne Ekonomi Yazıları İçinde (318-345), Umuttepe Yayınları, Kocaeli.

Badurlar, ì. Ö. (2008). Türkiye'de konut fiyatları ile makro ekonomik değişkenler arasındaki ilişkinin araştırılması. Anadolu Üniversitesi Sosyal Bilimler Dergisi, 8 (1), 223-238.

Büyüköztürk, Ş., Çakmak, E. K., Akgün, O. E., Karadeniz, S., \& Demirel, F. (2018). Bilimsel Araştırma Yöntemleri. Pegem Akademi Yayınları, Eskişehir.

Canbay, Ş., \& Mercan, D. (2020). Türkiye'de konut fiyatları, büyüme ve makroekonomik değişkenler arasındaki ilişkinin ekonometrik analizi. Yönetim ve Ekonomi Araştırmaları Dergisi, 18 (1), 176-200.

Carstensen, K., Hülsewig, O., \& Wollmershäuser, T. (2009). Monetary policy transmission and house prices: European cross-country evidence. Cesifo Working Paper, No. 2750, Center for Economic Studies and IFO Institute, Munich.

Christou, C., Gupta, R., Nyakabawo, W., \& Wohar, M.E. (2018). Do house prices hedge inflation in the US? A quantile cointegration approach. International Review of Economics and Finance, 54, 152-156.

Coşkun, Y. (2016). Konut fiyatları ve yatırımı: Türkiye için bir analiz. Niğde Üniversitesi İktisadi Ve Idari Bilimler Fakültesi Dergisi, 9 (2), $201-217$.

Coşkun, Y., \& Ertuğrul, M. (2016). House price return volatility trends in Turkey and Istanbul, Ankara, and Izmir. Journal of European Real Estate Research, 9 (1).

Çetin, G., \& Doğaner, A. (2017). İnşaat sektörü güven endeksi ve konut fiyat endeksi arasındaki ilişki: Türkiye için ampirik analiz. iktisat Politikası Araştırmaları Dergisi, 4 (2), 155-165.

Demary, M. (2009). The link between output, inflation, monetary policy and housing price dynamics. Munich Personal Repec Archive Mpra Paper No: 15978, University Library of Munich, Germany.

Dilber, İ., \& Sertkaya, Y. (2016). 2008 Finansal krizi sonrası Türkiye'de konut fiyatlarının belirleyicilerine yönelik analiz. Muş Alparslan Üniversitesi Sosyal Bilimler Dergisi, 4 (1), 11- 30.

Engin, C., \& Göllüce, E. (2016). 2008 Küresel finans krizi ve Türkiye üzerine yansımaları. Kahramanmaraş Sütçü Imam Üniversitesi Iktisadi ve Idari Bilimler Fakültesi Dergisi, 6, 27- 40.

Erol, I., \& Tirtiroglu, D. (2008). The inflation-hedging properties of Turkish REITS. Applied Economics, 40 (20), $2671-2696$.

Eryüzlü, H., \& Ekici, S. (2020). Konut fiyat endeksi ve reel döviz kuru ilişkisi: Türkiye örneği. iktisadi Idari ve Siyasal Araştırmalar Dergisi, 5 (12), 97105.

Goetzmann, W. N., \& Volaitis, E. (2006). Simulating real estate in the investment portfolio: model uncertainity and inflation hedging. Yale International Centre for Finance Working Paper, No:06-04, 1-39.

Goodhart, C., \& Hofmann, B. (2008). House prices, money, credit, and the macroeconomy. Oxford Review of Economic Policy, 24 (1), $180-205$.

Güriş, S., Akay, E.Ç., \& Güriş, B. (2017). Eviews ile Temel Ekonometri. Der Yayınları, İstanbul. 
Halıcıoğlu, F. (2007). The demand for new housing in Turkey: an application of ARDL model. Global Business and Economics Review, 9 (1), $62-74$. Hofmann, B., \& Peersman, G. (2017). Monetary policy transmission and tradeoffs in the United States: Old and new. BIS Working Papers No: 649, $1-27$.

Hossain, B., \& Latif, E. (2009). Determinants of housing price volatility in Canada: a dynamic analysis. Applied Economics, 41 (27), $3521-3331$. lacoviello, M. (2005). House prices, borrowing constraints, and monetary policy in the business cycle. American Economic Review, 95 (3), $739-764$. Ibrahim, I., Sundarasen, S.D., \& Shayuti, A.F. (2009). Property investment and inflation hedging in residential property: the case of district of Gombak, Selangor d.e. the lup. Journal of Applied Finance, 15 (2), 38-45.

İslamoğlu, B.and Nazlıoğlu, \& ş. (2019). Enflasyon ve konut fiyatları: İstanbul, Ankara ve İzmir için panel veri analizi. Siyaset, Ekonomi ve Yönetim Araştırmaları Dergisi, 7 (1), 93-99.

Jarocinski, M., \& Smets, F. (2008). House prices and the stance of monetary policy. ECB Working Paper, 891.

Jorda, O., Schularick, M., \& Taylor, A. M. (2015). Betting the house. Journal of International Economics, 96, 2-18.

Karadaş, H. A., \& Salihoğlu, E. (2020). Seçili makroekonomik değişkenlerin konut fiyatlarına etkisi: Türkiye örneği. Ekonomik ve Sosyal Araştırmalar Dergisi, 16 (1), 63- 80.

Kepili, E. I. Z. \& Masron, T. A. (2011). Real estate-foreign direct investment-growth in Malaysia: Re-framing eclectic paradigm. IPEDR, 7, $110-114$. Korkmaz, Ö. (2019). The relationship between housing prices and inflation rate in Turkey. International Journal of Housing Markets and Analysis, $13(3), 427-452$.

Kuang, W., \& Liu, P. (2015). Inflation and house prices: theory and evidence from 35 major cities in China. International Real Estate Review, 18 (1), 217-240.

Lebe, F., \& Akbaş, Y. E. (2014). Türkiye'nin konut talebinin analizi: 1970-2011. Atatürk Üniversitesi iktisadi ve Idari Bilimler Dergisi, 28 (1), $57-83$.

Lee, H. K. N. (2013). A cointegration analysis of inflation and real estate returns. Journal of Real Estate Portfolio Management, 19 (3), $207-223$.

Lotz, R. I. ve Gupta, R. (2013). The long-run relationship between house prices and Inflation in South Africa: an ARDL approach. International Journal of Strategic Property Management, 17, 188-198.

Milcheva, S., \& Sebastian, S. (2016). The housing market channel of monetary policy transmission in the Euro Area. Journal of European Real Estate Research, 9 (1), 76-97.

Özgen, F.B., \& Güloğlu, B. (2004). Türkiye'de iç borçların iktisadi etkilerinin var tekniğiyle analizi. METU Studies in Development, 31, 93-114.

Poterba, J. M. (19929. Tax reform and the housing market in the late 1980s: who knew what, and when did they know it. Real Estate and Credit Crunch, Federal Reserve Bank of Boston Conference Series No: 36, 230-251.

Szeidl, A., \& Chetty, R. (2004). Consumption commitments and asset prices. Society for Economic Dynamics. No. 354.

Central Bank of the Republic of Turkey, Elektronic Data Delivery System (TCMB EVDS), Https://Evds2.Tcmb.Gov.Tr/Index.Php?/Evds/Seriemarket/Access Date: May 12th, 2020.

Üçal, M. S, \& Gökkent. G. (2009). Macroeconomic factors affecting real estate markets in Turkey: a VAR analysis approach. Briefing Notes In Economics, 80, 1-10.

Valadez, R. M. (2010). The housing bubble and the GDP: a correlation perspective. Journal of Case Research in Business and Economics,3, 1-18.

Zandi, G., Mahadevan, A., Supramaniam, L., Aslam, A., \& Theng, L. K. (2015). The economical factors affecting residential property price: the case of Penang island. International Journal of Economics and Finance, 7(12), 45-55.

Zammit, V. (2010). Asymmetries in the monetary transmission mechanism in the Euro area: the case of the housing market. Bank of Valletta Review, 42, 76-107.

Zhou, X., \& Clements, S. (2010). The inflation hedging ability of real estate in China. Journal of Real Estate Portfolio Management, 16 (3), $267-277$. Zhu, H. (2006). The structure of housing finance markets and house prices in Asia. BIS Quarterly Review, December, 55-69. 
APPENDIX 1: Granger Causality Test Results

\begin{tabular}{|c|c|c|c|c|}
\hline $\begin{array}{l}\text { The Dependent } \\
\text { Variable }\end{array}$ & Excluded Variable & Chi-square Stat. & df & Probability (p) \\
\hline \multirow{6}{*}{$\Delta$ In_hpi } & $\Delta \ln \_$dir & 56.08538 & 15 & 0.0000 \\
\hline & $\Delta \mathrm{ln} \_$exc & 86.30392 & 15 & 0.0000 \\
\hline & $\Delta \mathrm{ln} \_$indprdc & 59.20449 & 15 & 0.0000 \\
\hline & $\Delta \Delta \mathrm{ln} \_$сpi & 87.38956 & 15 & 0.0000 \\
\hline & $\Delta$ ln_emply & 40.21184 & 15 & 0.0000 \\
\hline & All & 346.8900 & 75 & 0.0004 \\
\hline \multirow{6}{*}{$\Delta \ln \_$dir } & $\Delta \mathrm{ln} \_\mathrm{hpi}$ & 19.10273 & 15 & 0.2091 \\
\hline & $\Delta \mathrm{ln} \_$exc & 95.94800 & 15 & 0.0000 \\
\hline & $\Delta \mathrm{ln} \_$indprdc & 58.72552 & 15 & 0.0000 \\
\hline & $\Delta \Delta \mathrm{ln} \_\mathrm{cpi}$ & 49.51421 & 15 & 0.0000 \\
\hline & $\Delta \mathrm{ln} \_$emply & 28.14151 & 15 & 0.0207 \\
\hline & All & 304.3538 & 75 & 0.0000 \\
\hline \multirow{6}{*}{$\Delta \ln \_$exc } & $\Delta \ln \_h p i$ & 17.99078 & 15 & 0.2632 \\
\hline & $\Delta \ln \_$dir & 13.25528 & 15 & 0.5826 \\
\hline & $\Delta \mathrm{ln} \_$indprdc & 27.13335 & 15 & 0.0277 \\
\hline & $\Delta \Delta \mathrm{ln} \_\mathrm{cpi}$ & 32.73341 & 15 & 0.0051 \\
\hline & $\Delta \mathrm{ln} \_$emply & 14.22632 & 15 & 0.5084 \\
\hline & All & 92.79184 & 75 & 0.0800 \\
\hline \multirow{6}{*}{$\Delta \ln \_$sanayiue } & $\Delta \ln \_h p i$ & 12.20819 & 15 & 0.6632 \\
\hline & $\Delta \ln \_$dir & 19.12737 & 15 & 0.2080 \\
\hline & $\Delta \mathrm{ln} \_$exc & 7.149198 & 15 & 0.9534 \\
\hline & $\Delta \Delta \mathrm{ln} \_\mathrm{cpi}$ & 5.629513 & 15 & 0.9853 \\
\hline & $\Delta$ ln_emply & 21.70168 & 15 & 0.1159 \\
\hline & All & 83.83491 & 75 & 0.2270 \\
\hline \multirow{6}{*}{$\Delta \Delta \mathrm{In} \_c p i$} & $\Delta \mathrm{ln} \_\mathrm{hpi}$ & 11.40836 & 15 & 0.7231 \\
\hline & $\Delta \ln \_$dir & 9.138055 & 15 & 0.8702 \\
\hline & $\Delta \mathrm{ln} \_$exc & 31.81130 & 15 & 0.0068 \\
\hline & $\Delta \mathrm{ln} \_$indprdc & 9.825507 & 15 & 0.8306 \\
\hline & $\Delta \mathrm{ln} \_$emply & 11.07653 & 15 & 0.7472 \\
\hline & All & 97.13472 & 75 & 0.0438 \\
\hline \multirow{6}{*}{$\Delta$ In_emply } & $\Delta \mathrm{ln} \_\mathrm{hpi}$ & 10.06821 & 15 & 0.8154 \\
\hline & $\Delta \ln \_$dir & 14.47721 & 15 & 0.4897 \\
\hline & $\Delta \mathrm{ln} \_$exc & 11.03828 & 15 & 0.7499 \\
\hline & $\Delta \mathrm{ln} \_$indprdc & 17.25596 & 15 & 0.3038 \\
\hline & $\Delta \Delta \mathrm{ln} \_\mathrm{cpi}$ & 17.08514 & 15 & 0.3138 \\
\hline & All & 92.02636 & 75 & 0.0884 \\
\hline
\end{tabular}

